\title{
Sequencing and Characterization of Mitochondrial Protein- Coding Genes for Schizothorax niger (Cypriniformes: Cyprinidae) with Phylogenetic Consideration
}

\author{
Tasleem Akhtar $\left(\mathbb{D},{ }^{1,2}\right.$ Ghazanfar Ali $\mathbb{D}^{1},{ }^{1}$ Nuzhat Shafi $\left(\mathbb{D},{ }^{2}\right.$ Wasim Akhtar $\left(\mathbb{D},{ }^{3}\right.$ \\ Abdul Hameed Khan $(\mathbb{D}),{ }^{1}$ Zahid Latif ${ }^{D},{ }^{2}$ Abdul Wali ${ }^{D},{ }^{4}$ Syeda Ain-ul-Batool ${ }^{(D)}{ }^{1}$ \\ Abdul Rehman Khan $\mathbb{D}^{5},{ }^{5}$ Sadia Mumtaz ${ }^{(D},{ }^{1}$ Syed Iftikhar Altaf ${ }^{\circ},{ }^{1}$ Sundus Khawaja $\mathbb{D}^{1}{ }^{1}$ \\ Sadia $\left(\mathbb{D},{ }^{1}\right.$ Madiha Khalid $\left(\mathbb{D},{ }^{1,6}\right.$ Fazal Ur Rehman ${ }^{(D)},{ }^{7}$ and Qudir Javid ${ }^{1}{ }^{1}$ \\ ${ }^{1}$ Department of Biotechnology, University of Azad Jammu and Kashmir, Muzaffarabad, Pakistan \\ ${ }^{2}$ Department of Zoology, University of Azad Jammu and Kashmir, Muzaffarabad, Pakistan \\ ${ }^{3}$ Department of Botany, University of Azad Jammu and Kashmir, Muzaffarabad, Pakistan \\ ${ }^{4}$ Faculty of Life Sciences \& Informatics, BUITEMS, 87100 Quetta, Pakistan \\ ${ }^{5}$ Department of Chemistry, University of Azad Jammu and Kashmir, Muzaffarabad, Pakistan \\ ${ }^{6}$ Department of Biotechnology, Women University Bagh, Pakistan \\ ${ }^{7}$ Department of Microbiology, University of Balochistan, Quetta 87300, Pakistan
}

Correspondence should be addressed to Ghazanfar Ali; ali.phd.qau@gmail.com

Received 11 July 2020; Revised 29 September 2020; Accepted 18 November 2020; Published 7 December 2020

Academic Editor: Marco Fiore

Copyright $\odot 2020$ Tasleem Akhtar et al. This is an open access article distributed under the Creative Commons Attribution License, which permits unrestricted use, distribution, and reproduction in any medium, provided the original work is properly cited.

The present study was conducted to get more information about the genome and locate the taxonomic position of Schizothorax niger in Schizothoracinae through mitochondrial 13 protein-coding genes (PCGs). These PCGs for S. niger were found to be 11409 bps in length ranging from 165 (ATPase 8) to 1824 bps (NADH dehydrogenase subunit 5) and encode 3801 amino acids. In these PCGs, 4 genes overlap on the similar strands, while one shown on the opposite one: ATPase 6+8 and NADH dehydrogenase subunit 4+4L overlap by 7 nucleotides. Similarly, ND5-ND6 overlap by 4 nucleotides, while ATP6 and COIII overlap by 1 nucleotide. Similarly, four commonly used amino acids in S. niger were Leu (15.6 \%), Ile (10.12\%), Thr (8.12\%), and Ala $(8.7 \%)$. The results presented that COII, COIII, NDI, ND4L, and Cytb had substantial amino acid conservation as compared to the COI gene. Through phylogenetic analysis, it was observed that $S$. niger is closely linked with $S$. progastus, $S$. labiatus, S. plagiostomus, and S. nepalensis with high bootstrap values. The present study provided more genomic data to know the diversity of the mitochondrial genome and its molecular evolution in Schizothoracinae.

\section{Introduction}

Nowadays, mtDNA has been frequently used for species identification; it has phylogenetic, evolutionary, and population studies [1-3]. The vertebrate mtDNA is $16-20 \mathrm{~kb}$ in size and consists of 37 genes that coded 13 PCGs, 22 transfer RNAs, 2 ribosomal RNAs, and a d-loop region to check its replication and transcription $[4,5]$. Mitochondrial genome and its gene contents in fish are quite conserved with few exceptions in the rearrangement of genes $[6,7]$. The genome or gene-based studies are helpful for the better understanding of evolutionary and phylogenetic relationships among fishes $[3,8]$.

Recently, molecular and phylogenetic studies are helpful to solve some phylogenetic questions and persistent discrepancies among teleosts, for example, in the Cyprinidae [9]. Similarly, the evolutionary background of higher teleosts has also been explored through mitogenome studies [10]. For the analysis of phylogenetic trees, the information obtained through a single gene is mostly insufficient [11]. 
In the cyprinids, the phylogenetic approaches are based on the whole mitochondrial genome or the functional genes (13 PCGs) that are helpful for a better understanding of speciation and divergence [12]. Schizothoracinae (Cyprinidae) fishes represent the largest and most diverse taxon possessing more than 100 species and subspecies (http://www.fishbase .org) with a worldwide distribution [13-15]. Schizothoracinae are economically and commercially essential species living in fast-flowing and snowy rivers and streams including the Neelum and Jhelum Rivers in Azad Jammu and Kashmir $[13,16]$. Because of its tender flesh and delicious taste, the Schizothorax fish has become an important economic fish and been strongly targeted and overexploited by commercial fishermen, which have led to the decline of Schizothorax fish [17]. Moreover, in recent years, the Schizothorax species have suffered a dramatic decline due to overfishing, polluted water, and destruction of their spawning grounds that resulted in fragmentation of the habitat and impeded the migration of fishes [18, 19].

To overcome the declining fish population, the release of captive breeders into the wild has been helpful for effective conservation strategies to enhance the natural fish populations [20]. It is a widely accepted method to enhance the local populations of some fish species like Percocypris pingi and Chinese sturgeon (Acipenser sinensis) [21]. Similarly, for threatened Schizothorax species, artificially propagated individuals from hatcheries have also been released into the river to improve populations in the wild. However, in this genus, the discrepancies about morphology-based identification, molecular phylogeny, and evolutionary history were frequently observed $[22,23]$. Similarly, the available mitochondrial genome data are insufficient for Schizothorax species and especially for $S$. niger.

Therefore, genetic characterization of $S$. niger is an essential step for both fundamental science and its conservation strategy. The main purpose of the current study is to get more information about its genome and locate the taxonomic position of $S$. niger within Schizothoracinae. For this purpose, we characterize the mitochondrial protein-coding genes for $S$. niger and its phylogenetic relationship with other Schizothoracinae.

\section{Materials and Methods}

2.1. Sample Collection and DNA Extraction. The specimens of S. niger were collected from the Jhelum River $\left(34^{\circ} 19^{\prime} 46.3^{\prime \prime} \mathrm{N}\right.$ $\left.73^{\circ} 30^{\prime} 44.8^{\prime \prime} \mathrm{E}\right)$ with cast nets. All the fish samples were carefully handled to avoid the damages during studies. The Board of Advanced Studies and Research, University of Azad Jammu and Kashmir, Muzaffarabad, permits to conduct this study in Jhelum and Neelum Rivers of Muzaffarabad city. The collected fishes were anesthetized by immersion in $1 \%$ benzocaine in water and euthanized with an overdose of benzocaine. Following the analysis, the voucher specimens were preserved in $70 \%$ ethanol and deposited to the Zoological Museum Hall at the University of AJK, Pakistan. By following the classifications of Mirza [24] and Jhingran [25], these specimens were identified. All the collected specimens were obtained in compliance with the animal welfare laws, national policy, and local guidelines in Azad Jammu and Kashmir, Pakistan.

Approximately $0.1 \mathrm{~g}$ of tissue was sterilized with ethanol and washed three times with distilled water. The total DNA was isolated by a standard phenol-chloroform extraction method of Sambrook and Russell [26]. The extracted DNA was run on $1 \%$ agarose gels and visualized with a UV transilluminator. The results were recorded with a gel documentation system and quantified with a spectrophotometer at the $260 / 280 \mathrm{~nm}$ wavelengths. 16 sets of overlapping primers (Table 1) were used for the amplification of 13 proteincoding genes of the mitochondrial genome of $S$. niger with the use of the Primer-3 program. The mitochondrial DNA was amplified with polymerase chain reactions (PCR), which were performed in $25 \mu \mathrm{l}$ reaction volumes containing $14 \mu \mathrm{l}$ DMSO water, $3 \mu \mathrm{l}$ template DNA, $2.5 \mu \mathrm{l}$ Taq buffer, $0.5 \mu \mathrm{l}$ dNTPs, $1 \mu \mathrm{l}$ of each primer (forward and reverse), $2.5 \mu \mathrm{l}$ magnesium chloride, and $0.5 \mu \mathrm{l}$ Taq polymerase. For thorough mixing, the reaction mixture was vortexed and centrifuged for $30 \mathrm{~s}$ at $8000 \mathrm{rpm}$. The thermal cycling profile was $95^{\circ} \mathrm{C}$ for $3 \mathrm{~min} ; 39$ cycles of $95^{\circ} \mathrm{C}$ for $30 \mathrm{~s}$ (denature), $53^{\circ} \mathrm{C}$ for $30 \mathrm{~s}$ (anneal); and $72^{\circ} \mathrm{C}$ for $1 \mathrm{~min}$ (extension) and followed by a final extension at $72^{\circ} \mathrm{C}$ for $10 \mathrm{~min}$. The PCR products were purified with Exo-SapIT (Affymetrix purification kit) before cycle sequencing.

Bidirectional nucleotide (nt) sequencing was performed on an ABI Prism 3100 Genetic Analyzer (PE Applied Biosystems; Foster City, CA, USA) using gene-specific forward and reverse primers. Sequence editing was performed using the BioEdit program (http://www.mbio.ncsu.edu/BioEdit) to determine nucleotide and amino acid variants. The $S$. niger sequences were aligned by using the ClustalW algorithm of the MegAlign program in the LaserGene software package (DNAStar, Inc., Madison, WI). The sequence analyses were carried out using MEGA 6.06 [27] and DnaSP v5 [28] software. The nucleotide sequences with accession numbers (Table 2) are also available on GenBank. PCGs from 23 Schizothorax species retrieved from GenBank were concatenated and aligned using Sequencher and corrected by eye, yielding a total alignment of 11409-12 nucleotides to determine the sequence divergence among them. The nucleotide and amino acid composition, nucleotide substitutions, codon usage pattern, and relative synonymous codon usage (RSCU) of the 13 PCGs were examined with MEGA 6.0. Nucleotide compositional skew was calculated according to the formula: $\mathrm{AT}$-skew $=(\mathrm{A}-\mathrm{T}) /(\mathrm{A}+\mathrm{T})$ and $\mathrm{GC}$-skew $=(\mathrm{G}-\mathrm{C})$ $/(\mathrm{G}+\mathrm{C})$ [29]. The DAMBE software (v7.2.14) was used to calculate the entropy-based substitution saturation and its critical value [30]. The transitions and transversions against the genetic distance were also calculated through this software.

The Maximum Parsimony (MP) method and BEAST v2.6.2 [31] were used to compute the phylogenetic tree. The BEAST XML input file was generated using BEAUti v2.6.2 (part of the BEAST v2.6.2 package) with strict molecular clock approach and Yule process in tree prior. The MCMC chains were run for 10,000,000 generations, parameters were sampled every 1000 generations, and an initial $10 \%$ of the samples were discarded as burn-in. The tree results were 
TABle 1: Primers used for amplification of the protein-coding genes of S. niger.

\begin{tabular}{|c|c|c|c|}
\hline Primer name & Forward $\left(5^{\prime}-3^{\prime}\right)$ & Reverse $\left(5^{\prime}-3^{\prime}\right)$ & $T_{\mathrm{m}}$ \\
\hline COX1-F1 & $5^{\prime}$ AACCACAAAGACATTGGTAC $3^{\prime}$ & 5' GGTGTCCAAAGAATCAGAAT 3' $^{\prime}$ & 54 \\
\hline COX1-F2 & $5^{\prime}$ ATTCTGATTCTTTGGACACC $3^{\prime}$ & $5^{\prime}$ TTAATTTGATTGAATTTGAACAA $3^{\prime}$ & 53 \\
\hline COX11 & $5^{\prime}$ ACACAACTAGGATTCCAAGAC 3' & 5' AGGCGTCTTCTAGTATTAGTG 3’ & 60 \\
\hline COX111 & $5^{\prime}$ ATGGCCCACCAAGCACATGC $3^{\prime}$ & $5^{\prime}$ TATGAGCCTCATCAATAGATA $3^{\prime}$ & 60 \\
\hline Cyt b-F1 & $5^{\prime}$ ACCACTATGGCAAGCCTACG $3^{\prime}$ & 5' AGGAGATGTAAGATGGTTGCG 3' & 60 \\
\hline Cyt b-F2 & 5' TGCATTTCACTTCCTACTGCC $3^{\prime}$ & 5' GGGCAAGCTCATTCTAGTGC 3' & 60 \\
\hline ATPase 6 & $5^{\prime}$ TTGCGATCGCAATTGCACTC $3^{\prime}$ & 5' GTACGGCAGCAGTTAAGATT 3' & 59 \\
\hline ATPase 8 & 5' GGCCCTTGATTCGCAATTTT 3' & $5^{\prime}$ CTATCATGGTCAGTCTCAGG $3^{\prime}$ & 59 \\
\hline ND1 & $5^{\prime}$ ATGYTAAACATCYTAATTAC $3^{\prime}$ & $5^{\prime}$ CAGGGCGGTGTGTCATAGCA $3^{\prime}$ & 57 \\
\hline ND2 & $5^{\prime}$ CCATACGTACTTGCAATCCT $3^{\prime}$ & 5' AGTAATCCTAGGGTAGACACG 3' & 60 \\
\hline ND3 & 5' ATGAATCTRATTATAACMAT $3^{\prime}$ & 5' ATTCTGCTCATTYTAAGCC 3' & 52 \\
\hline ND4 & $5^{\prime}$ CAACCGCACATAGCCTCCT $3^{\prime}$ & $5^{\prime}$ GTTGGCTAGGTTGGCGATG $3^{\prime}$ & 60 \\
\hline ND4L & 5' ATGACACCCGTACAYTTCAG 3' & $5^{\prime}$ TTAGCATTGTAGAAGRTTAA $3^{\prime}$ & 55 \\
\hline ND5-F1 & $5^{\prime}$ ATGACACTAATTATACACTC $3^{\prime}$ & 5' GTGGAGGAATGCTAGTTGTGG 3' & 58 \\
\hline ND5-F2 & 5' CСАСАACTAGCATTCСТССАС $3^{\prime}$ & 5' GGTTAAGTATGTTTTGATTAT $3^{\prime}$ & 58 \\
\hline ND6 & 5' ACGAAGAGTCCCGCGGCTTAA 3' & 5' GACCTATTTCATGTTTCTGTT 3' & 61 \\
\hline
\end{tabular}

TABLE 2: Characteristics of studied samples used in this study.

\begin{tabular}{|c|c|c|c|c|c|c|}
\hline Species & Gene name & S. niger SN-01 & $\begin{array}{l}\text { NCBI accession no. } \\
\text { S. niger SN-02 }\end{array}$ & S. niger SN-03 & $\mathrm{A}+\mathrm{T}$ & $\mathrm{G}+\mathrm{C}$ \\
\hline \multirow{13}{*}{ S. niger } & NDI & MN264181 & MN264182 & MN264183 & 50.2 & 49.8 \\
\hline & ND2 & MN264184 & MN264185 & MN264186 & 52.2 & 47.9 \\
\hline & $\mathrm{COI}$ & MN264169 & MN264170 & MN264171 & 55.5 & 44.4 \\
\hline & COII & MN264175 & MN264176 & MN264177 & 57.6 & 42.4 \\
\hline & ATP8 & MN264205 & MN264206 & MN264207 & 63.6 & 36.3 \\
\hline & ATP6 & MN264202 & MN264203 & MN264204 & 58.2 & 41.8 \\
\hline & COIII & MN264178 & MN264179 & MN264180 & 54.3 & 45.8 \\
\hline & ND3 & MN264187 & MN264188 & MN264189 & 56.5 & 43.6 \\
\hline & ND4L & MN264193 & MN264194 & MN264195 & 52.5 & 47.4 \\
\hline & ND4 & MN264190 & MN264191 & MN264192 & 54.6 & 45.4 \\
\hline & ND5 & MN264196 & MN264197 & MN264198 & 54.8 & 45.2 \\
\hline & ND6 & MN264172 & MN264173 & MN264174 & 51.2 & 48.9 \\
\hline & CYTB & MN264199 & MN264200 & MN264201 & 53.3 & 46.6 \\
\hline
\end{tabular}

summarized using TreeAnnotator v2.6.2 (included in the BEAST package), with the maximum clade credibility tree, posterior probability limit set to 0.5 , and summarizing mean node heights. The phylogenetic tree was visualized using FigTree v1.4.4 (http://tree.bio.ed.ac.uk/software/figtree/). The DnaSP 5.0 program was used to calculate the total number of haplotypes, haplotype diversity $(\mathrm{Hd})$, and nucleotide diversity (Pi). Divergence times for all branching points were calculated using the maximum likelihood method by Tamura and Nei [32] model in MEGA 6.06.

\section{Results and Discussions}

3.1. Protein-Coding Genes' Features. The boundaries between PCGs of the mtDNA were observed by the alignment of their nucleotide and amino acid sequences and locating their start and stop codons by comparing with cyprinid fishes. The mitochondrial genome of $S$. niger coded 13 PCGs with 11409 bps in length. The lengths of PCGs ranged from 165 (ATPase 8) to 1824 bps (ND5) and encode 3801 amino acids. In these PCGs of the $S$. niger fish, 4 genes overlap on the 
TABLE 3: Characteristics of the protein-coding genes of S. niger.

\begin{tabular}{|c|c|c|c|c|c|c|}
\hline Gene & Size (bps) & Start & $\begin{array}{l}\text { Co } \\
\text { Stop }\end{array}$ & Amino acid & Intergenic nucleotide $^{\mathrm{a}}$ (bps) & Strand $^{\mathrm{b}}$ \\
\hline NDI & 975 & ATG & TAA & 319 & 0 & $\mathrm{H}$ \\
\hline ND2 & 1045 & ATG & $\mathrm{T}-$ & 340 & 0 & $\mathrm{H}$ \\
\hline $\mathrm{COI}$ & 1551 & GTG & TAA & 500 & 0 & $\mathrm{H}$ \\
\hline COII & 691 & ATG & $\mathrm{T}-$ & 225 & 0 & $\mathrm{H}$ \\
\hline ATP8 & 165 & ATG & TA- & 49 & -7 & $\mathrm{H}$ \\
\hline ATP6 & 684 & ATG & TAA & 223 & -1 & $\mathrm{H}$ \\
\hline COIII & 785 & ATG & TA- & 249 & 0 & $\mathrm{H}$ \\
\hline ND3 & 349 & ATG & $\mathrm{T}-$ & 112 & 0 & $\mathrm{H}$ \\
\hline ND4L & 297 & ATG & TAA & 97 & -7 & $\mathrm{H}$ \\
\hline ND4 & 1380 & ATG & T- & 445 & 0 & $\mathrm{H}$ \\
\hline ND5 & 1824 & ATG & TAA & 596 & -4 & $\mathrm{H}$ \\
\hline ND6 & 522 & ATG & TAA & 159 & 0 & $\mathrm{~L}$ \\
\hline CYTB & 1141 & ATG & T- & 367 & 0 & $\mathrm{H}$ \\
\hline
\end{tabular}

${ }^{a}$ Negative values indicate the overlapping nucleotides. ${ }^{\mathrm{b}} \mathrm{H}$ and $\mathrm{L}$ indicate that the gene is encoded by that strand.

TABLE 4: The base composition of the protein-coding genes of $S$. niger (the genes which are encoded by the L-strand are converted to complementary strand sequences).

\begin{tabular}{|c|c|c|c|c|c|c|c|c|c|c|c|c|c|c|c|c|}
\hline \multirow{2}{*}{ Region } & \multicolumn{4}{|c|}{ Base composition (\%) } & \multicolumn{4}{|c|}{ 1st position } & \multicolumn{4}{|c|}{ 2nd position } & \multicolumn{4}{|c|}{ 3rd position } \\
\hline & $\mathrm{A}$ & $\mathrm{T}$ & $\mathrm{C}$ & G & A & $\mathrm{T}$ & C & G & A & $\mathrm{T}^{2}$ & C & G & $\mathrm{A}$ & $\mathrm{T}$ & C & G \\
\hline \multicolumn{17}{|c|}{ H-strand coded } \\
\hline ND1 & 24.4 & 25.8 & 30.3 & 19.5 & 22.8 & 19 & 29.8 & 28 & 18.2 & 41 & 29.2 & 11.7 & 32.3 & 17 & 31.7 & 18.8 \\
\hline ND2 & 29.3 & 22.9 & 31.5 & 16.4 & 31.8 & 16 & 28.4 & 23.5 & 15.5 & 37 & 35.3 & 12.1 & 40.5 & 15 & 30.7 & 13.5 \\
\hline COI & 26.5 & 29.0 & 26.0 & 18.4 & 24.6 & 22 & 23.2 & 30.6 & 18.4 & 40 & 26.3 & 14.9 & 36.6 & 25 & 28.6 & 9.9 \\
\hline COII & 30.4 & 27.2 & 25.8 & 16.6 & 23.4 & 19 & 25.5 & 31.6 & 27.8 & 38 & 23.5 & 10.9 & 40 & 24 & 28.3 & 7.4 \\
\hline ATP8 & 33.9 & 29.7 & 24.2 & 12.1 & 32.7 & 31 & 20 & 16.4 & 23.6 & 31 & 32.7 & 12.7 & 45.5 & 27 & 20 & 7.3 \\
\hline ATP6 & 29.4 & 28.8 & 26.6 & 15.2 & 29.4 & 18 & 28.9 & 23.2 & 14.9 & 47 & 26.8 & 11 & 43.9 & 21 & 24.1 & 11.4 \\
\hline COIII & 27.5 & 26.8 & 28.2 & 17.6 & 20.6 & 26 & 26 & 27.9 & 21.4 & 36 & 26 & 16.4 & 40.6 & 18 & 32.6 & 8.4 \\
\hline ND3 & 28.1 & 28.4 & 28.7 & 14.9 & 21.4 & 25 & 29.1 & 24.8 & 17.2 & 45 & 25 & 12.9 & 45.7 & 16 & 31.9 & 6.9 \\
\hline ND4 & 28.4 & 26.2 & 28.6 & 16.8 & 29.1 & 22 & 28.9 & 20.4 & 16.1 & 41 & 27.6 & 15.7 & 40 & 16 & 29.3 & 14.3 \\
\hline ND4L & 24.9 & 27.6 & 30.6 & 16.8 & 21.2 & 25 & 28.3 & 25.3 & 14.1 & 40 & 29.3 & 16.2 & 39.4 & 17 & 34.3 & 9.1 \\
\hline ND5 & 30.0 & 24.8 & 29.8 & 15.4 & 33.4 & 18 & 25.3 & 23.2 & 20.2 & 40 & 27.8 & 11.5 & 26.3 & 16 & 36.3 & 11.5 \\
\hline Cytb & 25.9 & 27.4 & 28.9 & 17.7 & 23.4 & 23 & 26.2 & 27 & 20 & 42 & 25 & 13.2 & 34.5 & 17 & 35.5 & 12.9 \\
\hline Average & 26.85 & 24.35 & 30.9 & 17.95 & 26.15 & 22 & 26.63 & 25.15 & 18.95 & 39.83 & 27.87 & 13.26 & 38.77 & 19.08 & 30.27 & 10.95 \\
\hline \multicolumn{17}{|c|}{ L-strand coded } \\
\hline ND6 & 36.6 & 14.6 & 30.5 & 18.4 & 37.9 & 22 & 23 & 17.2 & 43.7 & 11 & 23 & 22.4 & 28.2 & 11 & 45.4 & 15.5 \\
\hline
\end{tabular}

similar strands, while one shown on the opposite one: ATPase $6+8$ and ND4+4L overlap by 7 nucleotides. Similarly, ND5-ND6 overlap by 4 nucleotides, while ATP6 and COIII overlap by 1 nucleotide. Among these, ATPase 6 and 8 genes' overlap is widespread in other vertebrate genomes; however, its size in mammals (40-46 bps) is larger as compared to fish (7-10 bps) [33].

Of the13 PCGs, 12 genes used ATG as start codon, while the COI gene is started with GTG. In particular, in teleosts, the start codon is ATG in all PCGs excluding the COI gene $[34,35]$. Similar findings were also observed in $S$. niger PCGs, depicting that COI could be an ancient gene in the evolutionary process of mitochondria. Many studies also reported ATG as an initiation codon of COI gene in many animals, such as Collichthys niveatus, Larimichthys crocea, Charybdis feriata, and Collichthys lucidus [36-39]. In the case of termination codon, five genes (ND1, ND4L, ND5, COI, and ATP8) were terminated with TAA, ATP8, and COIII with TA, while the rest of six genes (ND2ND3, ND4, ATP6, COII, and Cytb) have the incomplete stop codons ( $\mathrm{T}-$ ) (Table 3 ). The stop codons seem to have an ability to be changed in fish mitogenomes, suggesting that it might undergo a rapid evolutionary process $[5,40]$. It is widespread in vertebrate mitochondrial PCGs, and it is suggested that the incomplete termination codons are likely due to posttranscriptional modifications such as in 
Table 5

(a) Gene-wise codon usage patterns in S. niger

\begin{tabular}{|c|c|c|c|c|c|c|c|c|c|c|c|c|c|c|c|}
\hline Amino acid & Codon & ND1 & ND2 & COI & COII & ATP8 & ATP6 & COIII & ND3 & ND4 & ND4L & ND5 & ND6 & Cytb & Amino acids \\
\hline \multirow{2}{*}{ Phe } & UUU & 5 & 4 & 17 & 4 & 1 & 7 & 10 & 5 & 8 & 3 & 14 & 1 & 14 & \multirow{2}{*}{222} \\
\hline & UUC & 12 & 6 & 23 & 5 & 2 & 5 & 13 & 4 & 10 & 5 & 25 & 3 & 16 & \\
\hline \multirow{6}{*}{ Leu } & UUA & 6 & 8 & 7 & 5 & 5 & 14 & 6 & 6 & 17 & 3 & 13 & 1 & 6 & \multirow{7}{*}{596} \\
\hline & UUG & 1 & 2 & 0 & 1 & 0 & 0 & 0 & 0 & 2 & 3 & 2 & 0 & 2 & \\
\hline & CUU & 8 & 8 & 17 & 7 & 0 & 5 & 3 & 0 & 14 & 2 & 12 & 0 & 7 & \\
\hline & CUC & 13 & 7 & 10 & 1 & 0 & 10 & 7 & 6 & 15 & 3 & 22 & 2 & 7 & \\
\hline & CUA & 16 & 21 & 24 & 13 & 0 & 12 & 11 & 11 & 28 & 9 & 38 & 0 & 23 & \\
\hline & CUG & 16 & 20 & 6 & 1 & 0 & 5 & 4 & 3 & 12 & 2 & 9 & 0 & 16 & \\
\hline \multirow{3}{*}{ Ile } & AUU & 11 & 12 & 27 & 13 & 5 & 14 & 9 & 5 & 17 & 2 & 24 & 1 & 10 & \\
\hline & AUC & 12 & 13 & 12 & 4 & 1 & 9 & 8 & 3 & 20 & 0 & 24 & 2 & 19 & \multirow[t]{2}{*}{385} \\
\hline & AUA & 6 & 11 & 14 & 9 & 0 & 5 & 7 & 3 & 18 & 4 & 19 & 7 & 5 & \\
\hline \multirow[t]{2}{*}{ Met } & AUG & 4 & 4 & 10 & 3 & 1 & 5 & 2 & 1 & 9 & 2 & 13 & 1 & 6 & \multirow[t]{2}{*}{61} \\
\hline & GUU & 3 & 1 & 10 & 7 & 0 & 4 & 2 & 2 & 5 & 1 & 7 & 0 & 5 & \\
\hline \multirow{3}{*}{ Val } & GUC & 3 & 4 & 5 & 3 & 0 & 1 & 3 & 1 & 1 & 0 & 8 & 0 & 10 & \multirow{3}{*}{217} \\
\hline & GUA & 6 & 7 & 21 & 10 & 1 & 11 & 6 & 0 & 8 & 1 & 9 & 1 & 11 & \\
\hline & GUG & 11 & 1 & 6 & 1 & 1 & 1 & 4 & 2 & 3 & 0 & 7 & 0 & 2 & \\
\hline \multirow{6}{*}{ Ser } & UCU & 3 & 3 & 9 & 4 & 0 & 1 & 3 & 1 & 4 & 1 & 2 & 0 & 4 & \multirow{6}{*}{238} \\
\hline & UCC & 4 & 6 & 3 & 7 & 2 & 0 & 2 & 3 & 9 & 3 & 9 & 1 & 6 & \\
\hline & UCA & 8 & 7 & 14 & 2 & 1 & 3 & 5 & 1 & 10 & 2 & 15 & 2 & 8 & \\
\hline & UCG & 3 & 0 & 1 & 0 & 0 & 1 & 1 & 0 & 1 & 0 & 1 & 0 & 2 & \\
\hline & $\mathrm{AGU}$ & 0 & 0 & 0 & 0 & 1 & 0 & 0 & 0 & 2 & 0 & 1 & 2 & 0 & \\
\hline & AGC & 4 & 8 & 5 & 3 & 0 & 4 & 3 & 0 & 6 & 3 & 9 & 8 & 1 & \\
\hline \multirow{4}{*}{ Pro } & $\mathrm{CCU}$ & 4 & 2 & 5 & 1 & 1 & 2 & 0 & 0 & 2 & 0 & 5 & 0 & 1 & \multirow{4}{*}{224} \\
\hline & CCC & 10 & 7 & 9 & 3 & 1 & 3 & 5 & 2 & 7 & 2 & 9 & 11 & 5 & \\
\hline & CCA & 8 & 8 & 9 & 7 & 6 & 10 & 8 & 6 & 13 & 0 & 13 & 3 & 15 & \\
\hline & CCG & 2 & 2 & 5 & 2 & 0 & 2 & 0 & 0 & 5 & 0 & 2 & 1 & 0 & \\
\hline \multirow{4}{*}{ Thr } & $\mathrm{ACU}$ & 1 & 7 & 6 & 2 & 4 & 3 & 3 & 1 & 3 & 0 & 5 & 2 & 2 & \multirow{4}{*}{309} \\
\hline & ACC & 7 & 20 & 8 & 5 & 1 & 2 & 5 & 4 & 16 & 5 & 24 & 7 & 9 & \\
\hline & $\mathrm{ACA}$ & 9 & 18 & 21 & 3 & 0 & 12 & 13 & 4 & 17 & 3 & 23 & 0 & 8 & \\
\hline & ACG & 1 & 1 & 1 & 2 & 0 & 2 & 1 & 0 & 5 & 0 & 8 & 3 & 2 & \\
\hline \multirow{4}{*}{ Ala } & GCU & 2 & 6 & 7 & 3 & 1 & 2 & 3 & 0 & 2 & 2 & 4 & 1 & 5 & \multirow{4}{*}{333} \\
\hline & GCC & 20 & 12 & 22 & 5 & 0 & 9 & 11 & 3 & 17 & 4 & 30 & 6 & 12 & \\
\hline & GCA & 11 & 19 & 11 & 6 & 1 & 6 & 7 & 4 & 11 & 7 & 15 & 2 & 11 & \\
\hline & GCG & 2 & 5 & 5 & 2 & 0 & 3 & 1 & 0 & 5 & 0 & 4 & 1 & 5 & \\
\hline Tyr & UAU & 8 & 3 & 5 & 5 & 0 & 3 & 5 & 1 & 6 & 0 & 4 & 1 & 3 & 111 \\
\hline $1 y_{1}$ & UAC & 4 & 5 & 14 & 4 & 0 & 2 & 7 & 1 & 7 & 0 & 7 & 5 & 11 & 111 \\
\hline Ter & UAA & 1 & 0 & 1 & 0 & 0 & 1 & 0 & 0 & 0 & 1 & 1 & 10 & 0 & 23 \\
\hline 1er & UAG & 0 & 0 & 0 & 0 & 1 & 0 & 0 & 0 & 0 & 0 & 0 & 7 & 0 & 23 \\
\hline His & CAU & 2 & 2 & 5 & 2 & 1 & 1 & 5 & 0 & 6 & 1 & 2 & 5 & 5 & 112 \\
\hline 1115 & CAC & 3 & 4 & 14 & 8 & 1 & 2 & 11 & 1 & 5 & 3 & 11 & 5 & 7 & 112 \\
\hline $\mathrm{ln}$ & CAA & 6 & 13 & 8 & 7 & 1 & 8 & 9 & 3 & 11 & 2 & 19 & 5 & 6 & 100 \\
\hline Gint & CAG & 1 & 1 & 0 & 1 & 0 & 0 & 0 & 0 & 4 & 1 & 1 & 2 & 0 & 109 \\
\hline $\mathrm{Acn}_{\mathrm{c}}$ & AAU & 5 & 2 & 8 & 4 & 1 & 4 & 0 & 1 & 4 & 0 & 12 & 2 & 4 & 132 \\
\hline Asn & $\mathrm{AAC}$ & 7 & 6 & 7 & 2 & 1 & 6 & 1 & 2 & 6 & 2 & 19 & 12 & 14 & 152 \\
\hline I & AAA & 7 & 6 & 8 & 3 & 3 & 1 & 1 & 1 & 8 & 0 & 18 & 8 & 7 & 0 \\
\hline Lys & $\mathrm{AAG}$ & 0 & 3 & 0 & 1 & 0 & 0 & 1 & 0 & 3 & 0 & 4 & 5 & 2 & 90 \\
\hline
\end{tabular}


TABle 5: Continued.

\begin{tabular}{|c|c|c|c|c|c|c|c|c|c|c|c|c|c|c|c|}
\hline Amino acid & Codon & ND1 & ND2 & $\mathrm{COI}$ & COII & ATP8 & ATP6 & COIII & ND3 & ND4 & ND4L & ND5 & ND6 & Cytb & Amino acids \\
\hline \multirow{2}{*}{ Asp } & GAU & 2 & 0 & 4 & 2 & 0 & 0 & 1 & 2 & 0 & 0 & 3 & 1 & 3 & \multirow{2}{*}{77} \\
\hline & GAC & 2 & 4 & 10 & 10 & 1 & 1 & 4 & 2 & 3 & 1 & 10 & 4 & 7 & \\
\hline \multirow{2}{*}{ Glu } & GAA & 7 & 3 & 9 & 14 & 2 & 3 & 7 & 5 & 9 & 2 & 6 & 1 & 7 & \multirow{2}{*}{103} \\
\hline & GAG & 4 & 2 & 2 & 1 & 1 & 2 & 3 & 1 & 2 & 1 & 6 & 3 & 0 & \\
\hline \multirow{2}{*}{ Cys } & UGU & 0 & 1 & 0 & 0 & 0 & 0 & 1 & 0 & 0 & 1 & 0 & 0 & 0 & \multirow{2}{*}{28} \\
\hline & UGC & 0 & 0 & 1 & 2 & 0 & 0 & 1 & 1 & 5 & 2 & 5 & 5 & 3 & \\
\hline Ter & UGA & 5 & 8 & 16 & 5 & 5 & 4 & 12 & 4 & 15 & 1 & 11 & 2 & 11 & 99 \\
\hline $\operatorname{Trp}$ & UGG & 3 & 3 & 1 & 0 & 0 & 1 & 0 & 1 & 5 & 0 & 1 & 0 & 2 & 17 \\
\hline \multirow{6}{*}{ Arg } & CGU & 0 & 0 & 1 & 1 & 0 & 0 & 2 & 0 & 0 & 2 & 0 & 1 & 0 & \multirow{6}{*}{84} \\
\hline & CGC & 1 & 1 & 1 & 2 & 0 & 0 & 0 & 2 & 2 & 0 & 1 & 3 & 2 & \\
\hline & CGA & 4 & 3 & 4 & 3 & 0 & 5 & 3 & 0 & 8 & 1 & 6 & 2 & 4 & \\
\hline & CGG & 3 & 0 & 2 & 0 & 0 & 1 & 0 & 0 & 1 & 0 & 4 & 0 & 2 & \\
\hline & AGA & 0 & 0 & 0 & 0 & 0 & 0 & 0 & 0 & 0 & 0 & 0 & 5 & 0 & \\
\hline & AGG & 0 & 0 & 0 & 0 & 0 & 0 & 0 & 0 & 0 & 0 & 0 & 1 & 0 & \\
\hline \multirow{4}{*}{ Gly } & GGU & 2 & 2 & 8 & 1 & 0 & 1 & 1 & 0 & 2 & 2 & 1 & 2 & 2 & \multirow{4}{*}{231} \\
\hline & GGC & 1 & 4 & 4 & 1 & 1 & 1 & 4 & 2 & 6 & 1 & 8 & 5 & 6 & \\
\hline & GGA & 5 & 9 & 22 & 5 & 0 & 5 & 11 & 5 & 11 & 3 & 15 & 0 & 9 & \\
\hline & GGG & 10 & 3 & 12 & 2 & 0 & 3 & 5 & 0 & 9 & 0 & 8 & 3 & 8 & \\
\hline Total & & 325 & 348 & 517 & 230 & 55 & 228 & 261 & 116 & 460 & 99 & 608 & 174 & 380 & 3801 \\
\hline
\end{tabular}

(b) The relative synonymous codon usage of 13 PCGs in the S. niger

\begin{tabular}{|c|c|c|c|c|c|c|c|}
\hline Amino acid & Codon & Number & Frequency (\%) & Amino acid & Codon & Number & Frequency (\%) \\
\hline Phe & UUU & 52 & 0.84 & Tyr & UAU & 104 & 1.09 \\
\hline Phe & UUC & 72 & 1.16 & Tyr & UAC & 86 & 0.91 \\
\hline Leu & UUA & 97 & 1.47 & $*$ & UAA & 98 & 1.21 \\
\hline Leu & UUG & 62 & 0.94 & $*$ & UAG & 85 & 1.05 \\
\hline Leu & CUU & 59 & 0.89 & His & CAU & 74 & 0.91 \\
\hline Leu & CUC & 42 & 0.63 & His & $\mathrm{CAC}$ & 88 & 1.09 \\
\hline Leu & CUA & 72 & 1.09 & Gln & CAA & 110 & 1.31 \\
\hline Leu & CUG & 65 & 0.98 & Gln & CAG & 58 & 0.69 \\
\hline Ile & AUU & 72 & 1.09 & Asn & $\mathrm{AAU}$ & 90 & 1.09 \\
\hline Ile & AUC & 62 & 0.94 & Asn & $\mathrm{AAC}$ & 75 & 0.91 \\
\hline Ile & AUA & 64 & 0.97 & Lys & AAA & 83 & 1.36 \\
\hline Met & AUG & 34 & 1 & Lys & AAG & 39 & 0.64 \\
\hline Val & GUU & 11 & 0.57 & Asp & GAU & 50 & 1.06 \\
\hline Val & GUC & 22 & 1.14 & Asp & GAC & 44 & 0.94 \\
\hline Val & GUA & 21 & 1.09 & Glu & GAA & 46 & 1.02 \\
\hline Val & GUG & 23 & 1.19 & Glu & GAG & 44 & 0.98 \\
\hline Ser & UCU & 84 & 1.22 & Cys & UGU & 39 & 0.94 \\
\hline Ser & UCC & 98 & 1.42 & Cys & UGC & 44 & 1.06 \\
\hline Ser & UCA & 99 & 1.44 & * & UGA & 60 & 0.74 \\
\hline Ser & UCG & 48 & 0.7 & Trp & UGG & 66 & 1 \\
\hline Pro & $\mathrm{CCU}$ & 102 & 1.11 & Arg & $\mathrm{CGU}$ & 26 & 0.79 \\
\hline Pro & CCC & 114 & 1.25 & Arg & CGC & 26 & 0.79 \\
\hline Pro & CCA & 94 & 1.03 & Arg & CGA & 27 & 0.82 \\
\hline Pro & CCG & 56 & 0.61 & Arg & CGG & 40 & 1.22 \\
\hline Thr & $\mathrm{ACU}$ & 77 & 1.01 & Ser & $\mathrm{AGU}$ & 35 & 0.51 \\
\hline
\end{tabular}


TABLe 5: Continued.

\begin{tabular}{|c|c|c|c|c|c|c|c|}
\hline$\overline{\text { Amino acid }}$ & Codon & Number & Frequency (\%) & Amino acid & Codon & Number & Frequency (\%) \\
\hline Thr & ACC & 104 & 1.37 & Ser & AGC & 49 & 0.71 \\
\hline Thr & ACA & 83 & 1.09 & Arg & AGA & 41 & 1.25 \\
\hline Thr & ACG & 40 & 0.53 & Arg & AGG & 37 & 1.13 \\
\hline Ala & GCU & 45 & 0.96 & Gly & GGU & 24 & 0.78 \\
\hline Ala & GCC & 72 & 1.54 & Gly & GGC & 31 & 1.01 \\
\hline Ala & GCA & 51 & 1.09 & Gly & GGA & 31 & 1.01 \\
\hline Ala & GCG & 19 & 0.41 & Gly & GGG & 37 & 1.2 \\
\hline
\end{tabular}

*Represents termination codon.

polyadenylation $[10,41]$. The overall $\mathrm{A}+\mathrm{T}$ contents were $54.96 \%$ and $\mathrm{G}+\mathrm{C}$ contents were $45.03 \%$ of all 13 proteincoding genes (Table 2). The phenomenon of $\mathrm{A}+\mathrm{T}$ content higher than $\mathrm{G}+\mathrm{C}$ content was similar to that of Boleophthalmus pectinirostris, Channel catfish, Trachurus trachurus, Opsariichthys bidens, and Odontobutis potamophila [34, 42-44], depicting the conserved nature of mitochondrial genomes in the process of evolution.

The nucleotide compositions of the 13 mitochondrial protein-coding genes of the $S$. niger fishes are presented in Table 4. The overall nucleotide composition of 12 concatenated PCGs (H-strand coded) was $26.85 \%$ for A, $30.9 \%$ for $\mathrm{C}, 17.95 \%$ for $\mathrm{G}$, and $24.35 \%$ for $\mathrm{T}$, while the L-strand was as follows: A, $36.6 \%$; C, $30.5 \%$; G, $18.4 \%$; and $\mathrm{T}, 14.6 \%(\mathrm{~A}>\mathrm{C}>\mathrm{G}>\mathrm{T})$. In PCGs, though, the $1^{\text {st }}$ codon positions did not show any deflection of nucleotide composition, as reported in the study of Xenocyprinae [45, 46], albeit the $2^{\text {nd }}$ codon position showed lower $G(13.26 \%)$ and A (18.95\%) contents and higher proportion of $\mathrm{T}(39.83 \%)$ contents. Similarly, the lowest G (10.95\%) contents are in the $3^{\text {rd }}$ codon position and higher proportion of $\mathrm{A}$ residues (38.77\%) in H-strand of S. niger, which is in agreement with previous studies [47-50].

Gene-wise codon usage patterns of $S$. niger are depicted in Table 5(a). For amino acids with 4 -fold degenerate $3^{\text {rd }}$ position, codons ending with A are higher in S. niger as compared to those codons ending with $\mathrm{C}$ or $\mathrm{T}$. In 2 -fold degenerate codons, the proportion of $\mathrm{C}$ is greater compared to that of T. Similarly, G is the least common $3^{\text {rd }}$ position base excluding glycine and arginine (here, $\mathrm{G}$ is equal to $\mathrm{T}$ and $\mathrm{C}$ but quite lower than A). These patterns are generally similar across vertebrate groups $[10,33,48,49]$. In $S$. niger, the total length of PCGs is $11409 \mathrm{bps}$, showing the similar length to other Schizothoracinae (Table S2), indicating that the mtDNA is quite conserved in cyprinids.

The most frequently used codon is CUA (5.41\%) in 13 PCGs. Furthermore, it was observed that these PCGs coded twenty amino acids in S. niger, and the commonly used amino acid is leucine (596); however, the least commonly used amino acid is tryptophan (17). The hydrophobic amino acids (Ala, Ile, Leu, Phe, and Val) were greater compared to polar amino acids (Tyr, Cys, Ser, Asp, and Glu) in 13 protein-coding genes of $S$. niger. The RSCU of the 13 PCGs suggested that the overall 3803 codons were observed in $S$. niger and the most overused codon is GCC (1.54\%), while the less frequently used codon is GCG $(0.41 \%)$ (Table 5(b)).
3.2. Combined Analysis. In the present study, $11410 \mathrm{bps}$ of 13 protein-coding genes' sequences were obtained from 26 (3 in-group and 23 retrieved from NCBI) highly specialized Schizothoracinae fishes. Details regarding Schizothorax species retrieved from NCBI are available in Table S1. Sequence alignments of 24 haplotypes were observed in Schizothoracinae, showing that 8095 sites out of 11410 (71\%) were conserved while 3315 sites were mutated. Out of the mutated sites, 1975 (60\%) were parsimony informative polymorphic sites while 1340 were singleton. Transition mutation was higher compared to transversion. The outnumbered transition mutations follow other reports on mitochondrial DNA in teleost fish [51-54].

The number of haplotypes ranged from one (in all the NCBI sequences) to three (in three studied sequences) within the species. The 0 -fold degenerate sites are $7114(62.34 \%)$, while the 4 -fold degenerate sites are 1402 (12.28\%) out of 11410 . The average haplotype diversity (Hd) across all samples was 1.00 , while the nucleotide diversity $(\mathrm{Pi})$ was 0.232 .

$\mathrm{A}+\mathrm{T}$ and $\mathrm{G}+\mathrm{C}$ contents of $\mathrm{S}$. niger protein-coding genes were calculated and then compared to other members of Schizothoracinae. The overall base composition was 28.36 $\%$ A, 28.64\% C, 26.01\% T, and $16.98 \%$ G, with 54.38\% AT, respectively, shown in the similar nucleotide composition with the genus Schizothorax (Table S1). In addition, the proportion of conserved amino acids of 13 PCGs of Schizothorax species was also calculated. Five genes (ND1, COII, COIII, ND4L, and Cytb) were found to have more conserved amino acid sites as compared to others. Among these genes, COI was less conserved as compared to the abovementioned genes; moreover, $73.11 \%$ amino acid sites of this were invariable (Table S2).

The interspecific $\mathrm{K} 2 \mathrm{P}$ distances ranged from 0.06 to $7.77 \%$ (mean $1.105 \%$ ) for the protein-coding gene. Because of the sequence similarity, the intraspecific distances were 0.00 in studied samples of S. niger (SN-01 to SN-03), which could not represent the intraspecific distances of this species, while these sequences show the $0.06 \%$ intraspecific K2P distance with S. niger (NC-022866.1) retrieved from NCBI. The interspecific divergence of $S$. waltoni to other species is the maximum $(5.82-7.77 \%)$ as compared to other interspecific differences. The details of species genetic distances are displayed in Table 6.

The best fit model to sequence evolution was selected in $\mathrm{GTR}+\mathrm{I}+\mathrm{G}$ by the Akaike information criteria (AICc) (90532.960). Most of the mutation events were transitions 


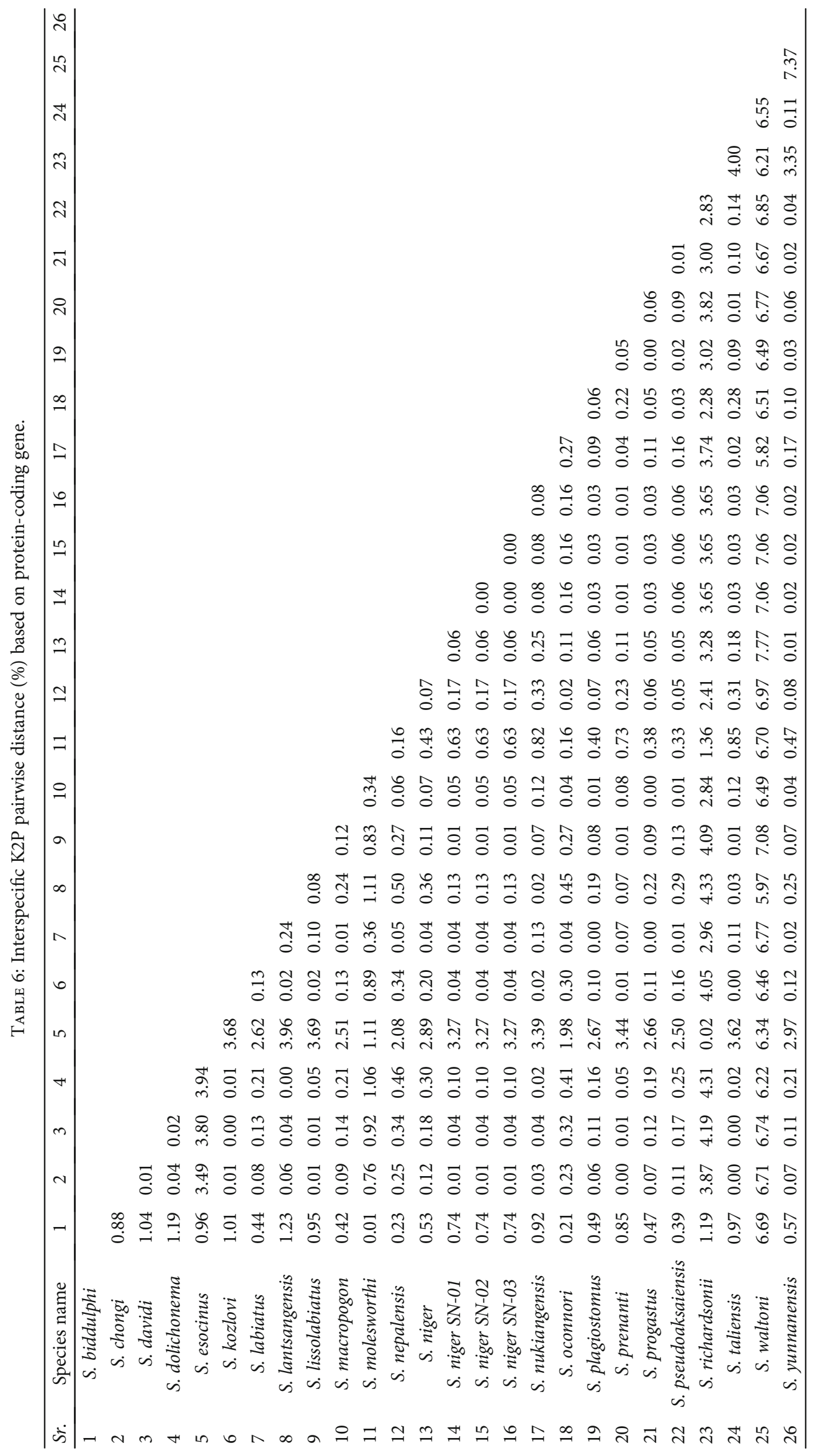




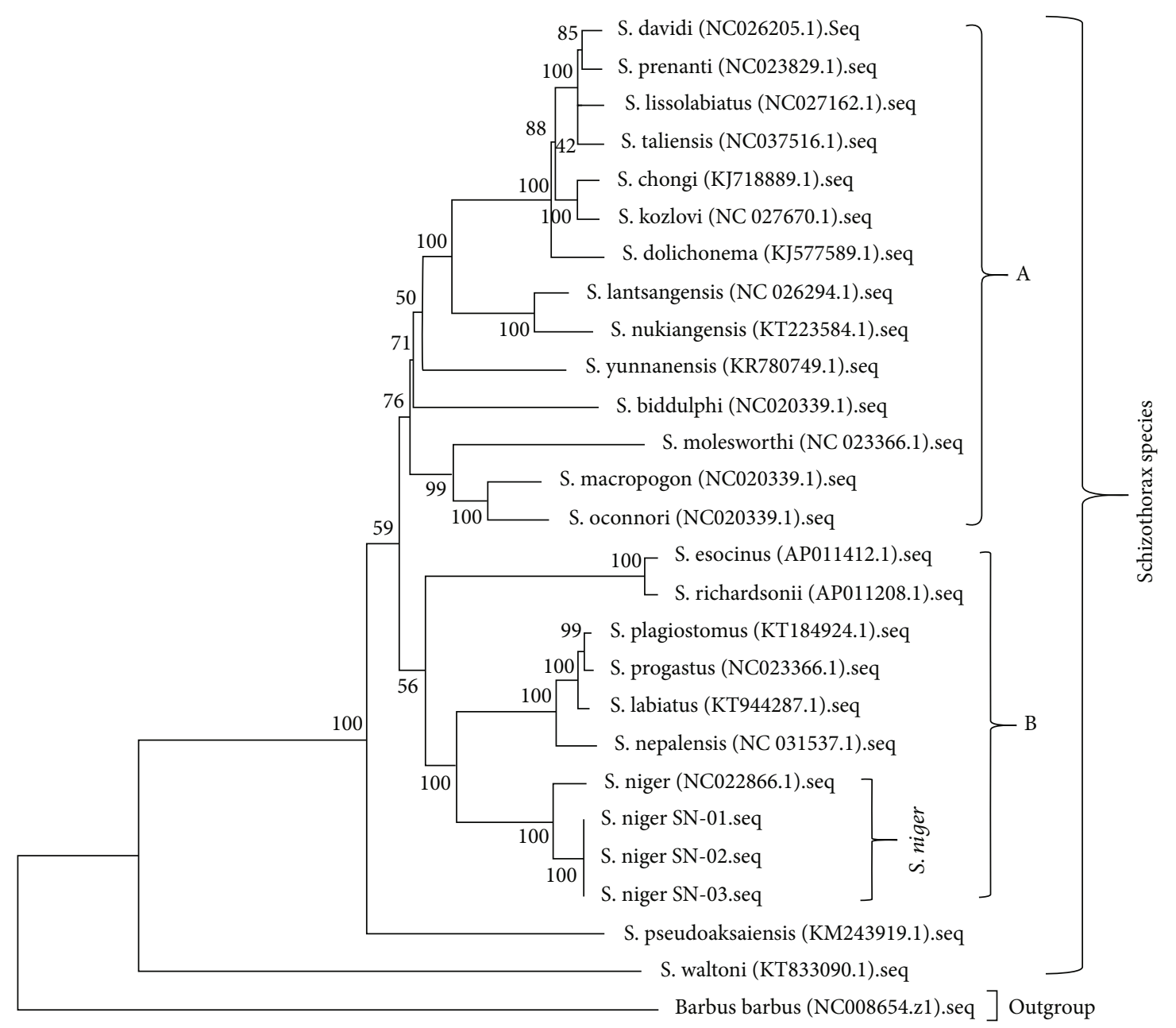

FIGURE 1: The phylogenetic relationship for fish of the Schizothoracinae with B. barbus (outgroup species) using the Maximum Parsimony method.

as compared to transversions. The more frequent transitions occur at the GA level (39.19\%) while the CT transitions were less frequent (Table S3). Similarly, transition/transversion bias $(R)$ is 11.21 .

3.3. Mitochondrial Genome Evolution. Phylogenetic analysis was used to estimate relationships among S. niger, 23 other Schizothorax species, and one outgroup (retrieved from NCBI) to assess historical information content of mitochondrial genomes.

3.4. Parsimony Analysis. The evolutionary history was inferred using the Maximum Parsimony method. The most parsimonious tree with length $=7602$ is shown. The consistency index is $0.555(0.447)$, the retention index is 0.669 (0.669), and the composite index is $0.371(0.299)$ for all sites and parsimony informative sites (in parentheses) when Barbus barbus was designated as the outgroup (Figure 1). These species created two main clades (A \& B) that support maximum bootstrap values. In the tree topology, the monophyly of $S$. davidi+S. prenanti, S. lissolabiatus $+S$. taliensis, and $S$. chongi+S. kozlovi forms a subcluster with S. dolichonema with maximum bootstrap support while $S$. dolichonema form the sister group with S. lantsangensis and S. nukiangensis with $100 \%$ bootstrap support. Similarly, S. molesworthi+S. macropogon $+S$. oconnori form the single subcluster and the base of the group with 99 and 100\% bootstrap support. S. yunnanensis and S. biddulphi do not show a close relationship with other species.

In clad B, S. niger forms a close link with $S$. nepalensis $+S$. labiatus + S. progastus + S. plagiostomus with maximum (99 and $100 \%$ ) bootstrap support. These species also show a close relationship with $S$. esocinus + S. richardsonii. S. pseudoaksaiensis and $S$. waltoni remained separate and do not show the close link with other species. Similarly, B. barbus was used as an outgroup and positioned as the base of the tree. Our findings are somewhat similar to the results of Khan et al. [54] and Bibi and Khan [55]. The tree generated in BEAST v2.6.2 through FigTree v1.4.4 (Figure 2) was not identical to the MP in the branching order of Schizothoracinae fishes. As shown in Figure 2, S. richardsonii and S. esocinus form the separate group from S. plagiostomus, S. progastus, S. labiatus, and $S$. nepalensis and remain at the base of $S$. niger.

Using DAMBE, the substitution saturation was assessed for protein-coding genes of $S$. niger. In these genes, no saturation was observed as shown by a linear correlation when 


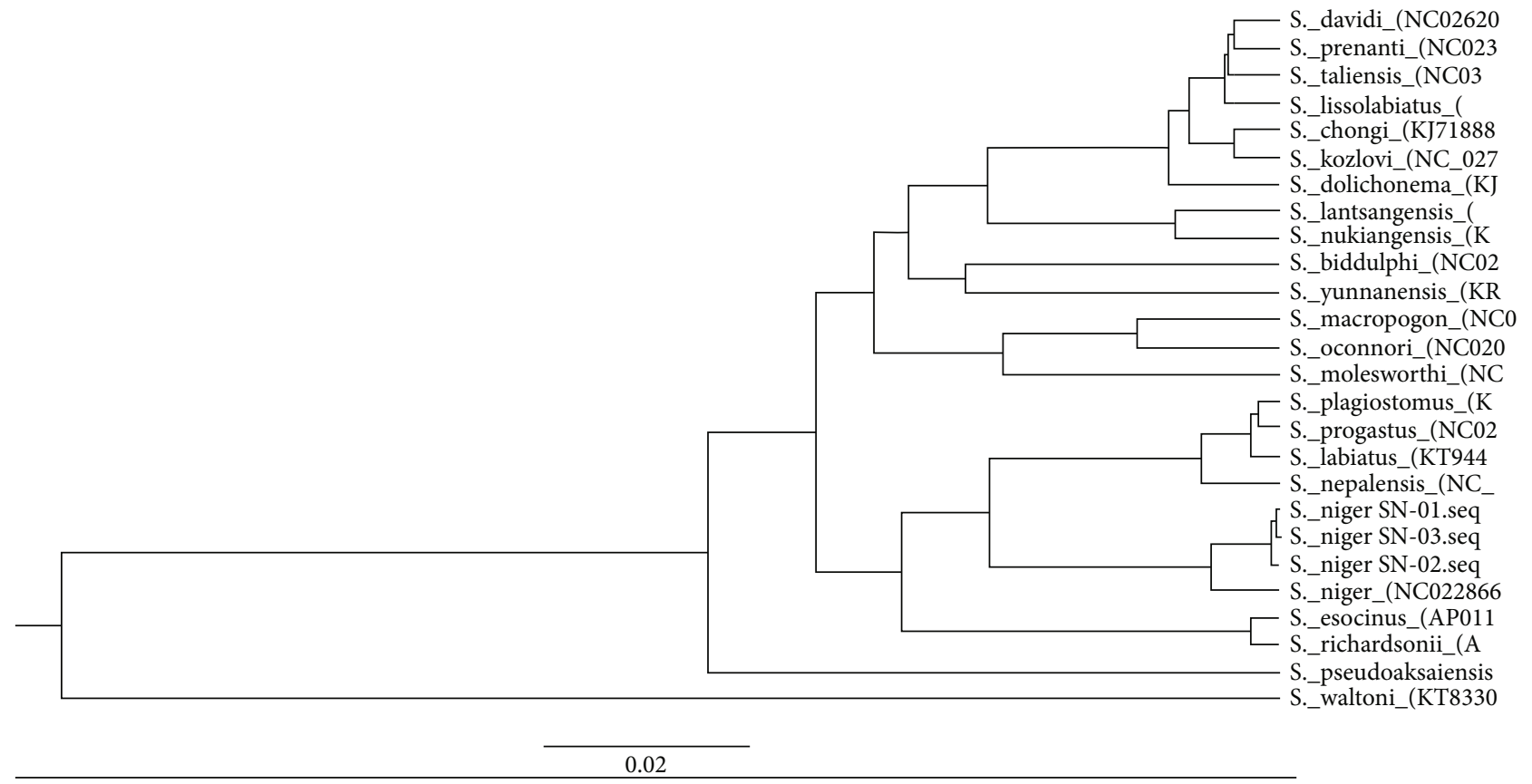

FIgURE 2: Tree topology is derived from BEAST (FigTree) for the Schizothoracinae.

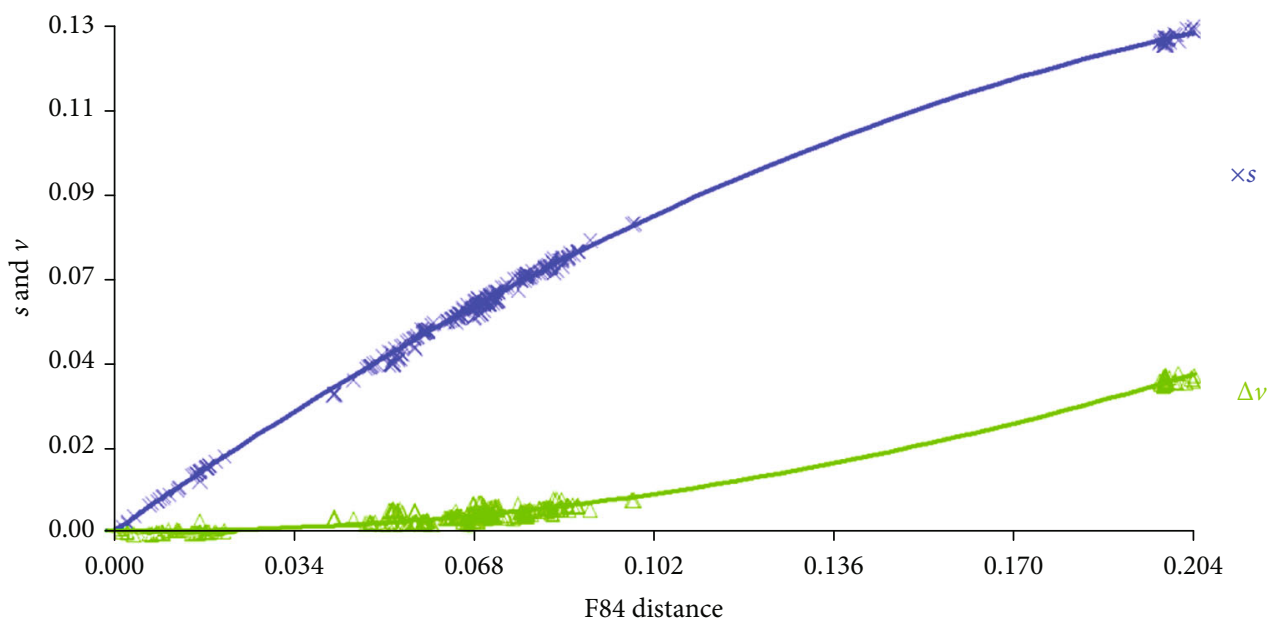

FIGURE 3: Substitution saturation plot of protein-coding genes of $S$. niger. The number of transitions $(s)$ and transversions $(v)$ is plotted against F84 genetic distance. A linear correlation is sustained for both transitions and transversions as expected in the absence of saturation.

the transitions and transversions were plotted against genetic distance (Figure 3). Similarly, the rate of transitional substitutions was higher than that of transversions; similar findings were also reported from Barik et al. [56]. It was also confirmed from a significantly higher $(P<0.001)$ Iss.c value of symmetrical (0.849) and asymmetrical (0.631) as compared to Iss values $(0.085)$. These results depicted that the nucleotide substitutions are not saturated and the data is suitable for phylogenetic study also reported by $\mathrm{Li}$ et al. [57] while studying the problematic Cytb gene sequences of fishes from NCBI.

Through the molecular analysis, the branching time is also estimated along the branching order. The molecular clock estimates of Schizothoracinae fishes are based on a sequence divergence rate of approximately $2.0 \%$ per MY [46]. Applying the abovementioned sequence divergence rate, the divergence between $S$. niger and other Schizothorax species (S. plagiostomus, S. progastus, S. labiatus, and S. nepalensis) is $0.04 \%$. Similarly, other Schizothoracinae species also show the sequence divergence rate ranging from 0.04 to $0.06 \mathrm{MY}$ as shown in Figure 4. Bars around each node represent $95 \%$ confidence intervals which were computed using the method described in Tamura et al. [27]. Our study did not show any conflict with the geological event that causes the uplifting of Himalaya in the late Pliocene to middle Pleistocene (0.5 MY BP) [58]. 


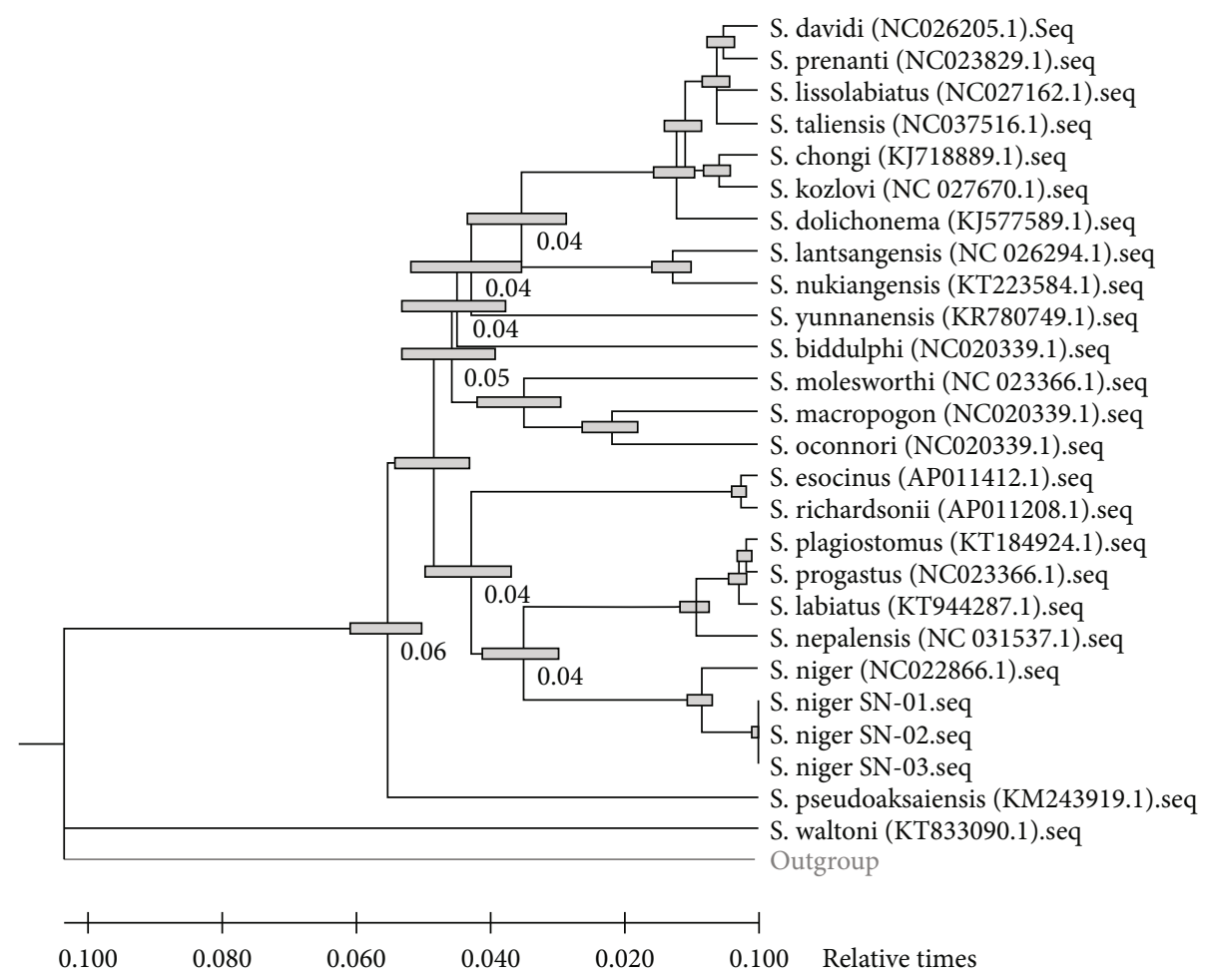

Figure 4: Relative time of divergence was estimated for the Schizothorax species by the maximum likelihood method. Branch lengths are proportional to divergence times (MY).

This is the first study to report genetic data on S. niger from the cold water bodies of Azad Jammu and Kashmir, where there is a need to devise conservation and management plans for the exploited cold-water fish species. Through this study, the genetic diversity and phylogenetic relationships among cyprinids and especially of the focal endemic $S$. niger are well explained. Their low intraspecific divergence may cause a threatening condition, and policy actions promoting conservation must be taken immediately. Natural populations need to be maintained at a size sufficient to retain genetic diversity, as this helps to minimize their risk of extinction. Hence, it needs to be spotlighted to conserve the data of genetic diversity. It is mandatory to prevent overfishing, particularly to prohibit fishing throughout the reproductive season. The authors recommend using proteincoding and other mtDNA regions to investigate the genetic divergence and phylogenetic studies of other fish species in freshwater ecosystems in the world.

\section{Data Availability}

The data that support the findings of this study are openly available in the repository under Accession: MN264169MN264207 (https://www.ncbi.nlm.nih.gov/nuccore/MN264 169-MN264207).

\section{Conflicts of Interest}

The authors alone are responsible for the content and writing of the paper. The authors report no conflicts of interest.

\section{Acknowledgments}

The authors sincerely acknowledge Raja Mubarak Ali for helping with sample collection.

\section{Supplementary Materials}

Table S1: composition and skewness in the PCGs of Schizothorax mitogenomes. Table S2: proportion of conserved amino acid sites in 13 PCGs of Schizothorax species. Table S3: maximum likelihood estimate of substitution matrix in Schizothoracinae. Rates of different transitional substitutions are shown in bold, and those of transversion substitutions are shown in italics. (Supplementary Materials)

\section{References}

[1] V. S. Domingues, C. Faria, S. Stefanni, R. S. Santos, A. Brito, and V. C. Almada, "Genetic divergence in the Atlantic-Mediterranean Montagu's blenny, Coryphoblennius galerita (Linnaeus 1758) revealed by molecular and morphological characters," Molecular Ecology, vol. 16, no. 17, pp. 3592 3605, 2007.

[2] A. Bucklin and D. Steinke, "DNA barcoding of marine metazoa," Annual Review in Marine Science, vol. 3, no. 1, pp. 471-508, 2011.

[3] C. D. Ortega-Ortiz, F. R. Elorriaga-Verplancken, A. OlivosOrtiz, M. A. Liñán-Cabello, and M. H. Vargas-Bravo, "Insights into the feeding habits of false killer whales (Pseudorca crassidens) in the Mexican Central Pacific," Aquatic Mammals, vol. 40, no. 4, pp. 386-393, 2014. 
[4] J. G. Inoue, M. Miya, K. Tsukamoto, and M. Nishida, "Basal actinopterygian relationships: a mitogenomic perspective on the phylogeny of the "ancient fish"," Molecular Phylogenetics and Evolution, vol. 26, no. 1, pp. 110-120, 2003.

[5] Z. Peng, J. Wang, and S. He, "The complete mitochondrial genome of the helmet catfish Cranoglanis bouderius (Siluriformes: Cranoglanididae) and the phylogeny of otophysan fishes," Gene, vol. 376, no. 2, pp. 290-297, 2006.

[6] R. Shao, N. J. Campbell, and S. C. Barker, "Numerous gene rearrangements in the mitochondrial genome of the wallaby louse, Heterodoxus macropus (Phthiraptera)," Molecular Biology and Evolution, vol. 18, no. 5, pp. 858-865, 2001.

[7] L. Yuan and C. Zhaoxia, "Complete mitochondrial genome of the Asian paddle crab Charybdis japonica (Crustacea: Decapoda: Portunidae): gene rearrangement of the marine brachyurans and phylogenetic considerations of the decapods," Molecular Biology Reports, vol. 37, pp. 2559-2569, 2009.

[8] N. Karaiskou, A. P. Apostolidis, A. Triantafyllidis, A. Kouvatsi, and C. Triantaphyllidis, "Genetic identification and phylogeny of three species of the genus Trachurus based on mitochondrial DNA analysis," Marine Biotechnology, vol. 5, pp. 493504, 2003.

[9] S. He, R. L. Mayden, X. Wang et al., "Molecular phylogenetics of the family Cyprinidae (Actinopterygii: Cypriniformes) as evidenced by sequence variation in the first intron of S7 ribosomal protein-coding gene: further evidence from a nuclear gene of the systematic chaos in the family," Molecular Phylogenetics and Evolution, vol. 46, no. 3, pp. 818-829, 2008.

[10] M. Miya, H. Takeshima, H. Endo et al., "Major patterns of higher teleostean phylogenies: a new perspective based on 100 complete mitochondrial DNA sequences," Molecular Phylogenetics and Evolution, vol. 26, no. 1, pp. 121-138, 2003.

[11] A. S. Afonso, F. H. Hazin, F. Carvalho et al., "Fishing gear modifications to reduce elasmobranch mortality in pelagic and bottom longline fisheries off Northeast Brazil," Fisheries Research, vol. 108, no. 2-3, pp. 336-343, 2011.

[12] X. Kong, X. Wang, X. Gan, J. Li, and S. He, "Phylogenetic relationships of Cyprinidae (Teleostei: Cypriniformes) inferred from the partial S6K1 gene sequences and implication of indel sites in intron 1," Science China Life Sciences, vol. 50, no. 6, pp. 780-788, 2007.

[13] T. Akhtar and G. Ali, "DNA barcoding of Schizothorax species from the Neelum and Jhelum Rivers of Azad Jammu and Kashmir," Mitochondrial DNA Part B, vol. 1, no. 1, pp. 934936, 2016.

[14] T. Akhtar, N. Shafi, and G. Ali, "DNA bar-coding of snow trout (S. plagiostomus) from Neelum and Jhelum rivers of Azad Jammu and Kashmir, Pakistan," International Journal of Biosciences, vol. 10, pp. 302-310, 2017.

[15] T. Akhtar, G. Ali, N. Shafi, and A. Rauf, "Molecular characterization of subfamily Schizothoracinae (Teleostei: Cyprinidae) using complete sequence of mitochondrial 16S rRNA gene," Pakistan Journal of Zoology, vol. 52, pp. 273-282, 2020.

[16] T. Akhtar, N. Shafi, and G. Ali, "Length-weight relationship, condition factor and sex ratio of snow trout (S. plagiostomus) from Neelum and Jhelum rivers, Muzaffarabad, Azad Kashmir," International Journal of Fisheries and Aquatic Studies, vol. 4, pp. 513-517, 2016.

[17] J. Song, Z. B. Song, B. S. Yue, and W. J. Zheng, “Assessing genetic diversity of wild populations of Prenant $\otimes 9$ s schizothoracin, Schizothorax prenanti, using AFLP markers," Environmental Biology of Fishes, vol. 77, no. 1, pp. 79-86, 2006.
[18] S. M. Ahmad, F. A. Bhat, M. U. H. Balkhi, and B. A. Bhat, "Mitochondrial DNA variability to explore the relationship complexity of Schizothoracine (Teleostei: Cyprinidae)," Genetica, vol. 142, no. 6, pp. 507-516, 2014.

[19] C. Goel, P. K. Sahoo, and A. Barat, "Complete mitochondrial genome organization of S. plagiostomus (Heckel, 1838)," Mitochondrial DNA Part A, vol. 27, pp. 113-114, 2016.

[20] X. Li, Y. Deng, K. Yang et al., "Genetic diversity and structure analysis of Percocypris pingi (Cypriniformes: Cyprinidae): implications for conservation and hatchery release in the Yalong River," PloS One, vol. 11, no. 12, article e0166769, 2016.

[21] Q. Li, Z. Z. Liu, and J. N. Gu, "Mitochondrial gene rearrangement and molecular marker selection for Odontobutis potamophila," Journal of Fishery Sciences of China, vol. 22, pp. 858-866, 2015.

[22] L. Yang, M. Arunachalam, T. Sado et al., "Molecular phylogeny of the cyprinid tribe Labeonini (Teleostei: Cypriniformes)," Molecular Phylogenetics and Evolution, vol. 65, no. 2, pp. 362-379, 2012.

[23] F. A. Mir, J. I. Mir, and S. Chandra, "Phenotypic variation in the Snowtrout Schizothorax richardsonii (Gray, 1832) (Actinopterygii: Cypriniformes: Cyprinidae) from the Indian Himalayas," Contribution to Zoology, vol. 82, no. 3, pp. 115122, 2013.

[24] M. A. Mirza, "Contribution to the systematics of the Schizothoracinae fishes (Pisces: Cyprinidae) with the description of three new tribes," Pakistan Journal of Zoology, vol. 23, pp. 339-341, 1991.

[25] V. Jhingran, "Culture of air-breathing fishes and non-airbreathing predatory carnivorous fishes," in Fish and Fisheries of India, pp. 498-503, Hindustan Publishing Corporation, Delhi, India, 3rd edition, 1991.

[26] J. Sambrook and D. W. Russell, Molecular Cloning: A Laboratory Manual, Cold Spring Harbor Laboratory Press, New York (NY), 3rd edition, 2001.

[27] K. Tamura, G. Stecher, D. Peterson, A. Filipski, and S. Kumar, "MEGA6: molecular evolutionary genetics analysis version 6.0," Molecular Biology and Evolution, vol. 30, no. 12, pp. 2725-2729, 2013.

[28] J. Rozas, J. C. Sánchez-DelBarrio, X. Messeguer, and R. Rozas, "DnaSP, DNA polymorphism analyses by the coalescent and other methods," Bioinformatics, vol. 19, no. 18, pp. 24962497, 2003.

[29] N. T. Perna and T. D. Kocher, "Patterns of nucleotide composition at fourfold degenerate sites of animal mitochondrial genomes," Journal of Molecular Evolution, vol. 41, no. 3, pp. 353-358, 1995.

[30] X. Xia, "DAMBE5: a comprehensive software package for data analysis in molecular biology and evolution," Molecular Biology and Evolution, vol. 30, no. 7, pp. 1720-1728, 2013.

[31] R. Bouckaert, J. Heled, D. Kühnert et al., "BEAST 2: a software platform for Bayesian evolutionary analysis," PLoS Computational Biology, vol. 10, no. 4, article e1003537, 2014.

[32] K. Tamura and M. Nei, "Estimation of the number of nucleotide substitutions in the control region of mitochondrial DNA in humans and chimpanzees," Molecular Biology and Evolution, vol. 10, no. 3, pp. 512-526, 1993.

[33] R. E. Broughton, J. E. Milam, and B. A. Roe, "The complete sequence of the zebrafish (Danio rerio) mitochondrial genome and evolutionary patterns in vertebrate mitochondrial DNA," Genome Research, vol. 11, no. 11, pp. 1958-1967, 2001. 
[34] X. Wang, J. Wang, S. He, and R. L. Mayden, "The complete mitochondrial genome of the Chinese hook snout carp _Opsariichthys bidens_(Actinopterygii: Cypriniformes) and an alternative pattern of mitogenomic evolution in vertebrate," Gene, vol. 399, no. 1, pp. 11-19, 2007.

[35] R. Li, G. Wang, Z. Y. Wen et al., "Complete mitochondrial genome of a kind of snakehead fish Channa siamensis and its phylogenetic consideration," Genes \& Genome, vol. 41, no. 2, pp. 147-157, 2019.

[36] Z. Cui, Y. Liu, C. P. Li, F. You, and K. H. Chu, "The complete mitochondrial genome of the large yellow croaker, Larimichthys crocea (Perciformes, Sciaenidae): unusual features of its control region and the phylogenetic position of the Sciaenidae," Gene, vol. 432, no. 1-2, pp. 33-43, 2009.

[37] Y. Cheng, R. Wang, Y. Sun, and T. Xu, “The complete mitochondrial genome of the small yellow croaker and partitioned Bayesian analysis of Sciaenidae fish phylogeny," Genetics and Molecular Biology, vol. 35, no. 1, pp. 191-199, 2012.

[38] J. Jiao, F. M. Shi, and J. G. Gao, "Two new species of the genus Xizicus, 1993 (Orthoptera: Tettigoniidae: Meconematinae) from Xizang, China," Zootaxa, vol. 3694, no. 3, pp. 296-300, 2013.

[39] H. Ma, C. Ma, C. Li et al., "First mitochondrial genome for the red crab (Charybdis feriata) with implication of phylogenomics and population genetics," Scientific Reports, vol. 5, no. 1, article 11524, 2015.

[40] Y. Kim, H. Kweon, I. Kim, Y. Lee, J. Kim, and J. Lee, "The complete mitochondrial genome of the floating goby, Gymnogobius petschiliensis (Perciformes, Gobiidae)," Molecules and Cells, vol. 17, no. 3, pp. 446-453, 2004.

[41] H. Ishiguro, K. Yasuda, N. Ishii et al., "Enhancement of oxidative damage to cultured cells and Caenorhabditis elegans by mitochondrial electron transport inhibitors," IUBMB Life (International Union of Biochemistry and Molecular Biology: Life), vol. 51, no. 4, pp. 263-268, 2001.

[42] G. C. Waldbieser, A. L. Bilodeau, and D. J. Nonneman, "Complete sequence and characterization of the channel catfish mitochondrial genome," DNA Sequence, vol. 14, pp. 265-277, 2009.

[43] Y. Takashima, T. Morita, and M. Yamashita, "Complete mitochondrial DNA sequence of Atlantic horse mackerel Trachurus trachurus and molecular identification of two commercially important species $T$. trachurus and T. japonicus using PCR-RFLP," Fisheries Science, vol. 72, no. 5, pp. 10541065, 2006.

[44] Z. Z. Liu, C. T. Wang, L. B. Ma, A. Y. He, J. Q. Yang, and W. Q. Tang, "Complete mitochondrial genome of the mudskipper Boleophthalmus pectinirostris (Perciformes, Gobiidae): repetitive sequences in the control region," Mitochondrial DNA, vol. 23, no. 1, pp. 31-33, 2012.

[45] W. Xiao, Y. Zhang, and H. Liu, "Molecular systematics of Xenocyprinae (Teleostei: Cyprinidae): taxonomy, biogeography, and coevolution of a special group restricted in East Asia," Molecular Phylogenetics and Evolution, vol. 18, no. 2, pp. 163173, 2001.

[46] D. L. Qi, S. C. Guo, W. J. Tang, J. Yang, and X. Q. Zhao, "Molecular systematics of morphologically similar fishes in the Schizothoracinae in Nanmenxia River, with implication for morphological convergent evolution," Acta Zoologica Sinica, vol. 52, pp. 862-870, 2006.

[47] K. Saitoh, K. Hayashizaki, Y. Yokoyama, T. Asahida, H. Toyohara, and Y. Yamashita, "Complete nucleotide sequence of Japanese flounder (Paralichthys olivaceus) mitochondrial genome: structural properties and cue for resolving teleostean relationships," Journal of Heredity, vol. 91, no. 4, pp. 271-278, 2000.

[48] K. Mabuchi, M. Miya, Y. Azuma, and M. Nishida, "Independent evolution of the specialized pharyngeal jaw apparatus in cichlid and labrid fishes," BMC Evolutionary Biology, vol. 7, no. 1, p. 10, 2007.

[49] D. J. Oh, B. S. Oh, M. M. Jung, and Y. H. Jung, "Complete mitochondrial genome of three Branchiostegus (Perciformes, Malacanthidae) species: genome description and phylogenetic considerations," Mitochondrial DNA, vol. 21, no. 5, pp. 151$159,2010$.

[50] D. X. Chen, W. Y. Chu, X. L. Liu et al., "Phylogenetic studies of three sinipercid fishes (Perciformes: Sinipercidae) based on complete mitochondrial DNA sequences," Mitochondrial DNA, vol. 23, no. 2, pp. 70-76, 2012.

[51] W. S. Lakra, M. Goswami, and A. Gopalakrishnan, "Molecular identification and phylogenetic relationships of seven Indian Sciaenids (Pisces: Perciformes, Sciaenidae) based on 16S rRNA and cytochrome c oxidase subunit I mitochondrial genes," Molecular Biology Reports, vol. 36, no. 5, pp. 831-839, 2009.

[52] M. Singh, W. S. Lakra, S. N. Bahuguna, and Y. P. Kartavtsev, "Cytochrome b gene sequence divergence of seven sisorid species of catfish genus Glyptothorax (siluriformes, sisoridae) from India," Molecular Biology Reports, vol. 39, no. 4, pp. 4275-4282, 2012.

[53] S. Kumar, G. Stecher, and K. Tamura, "MEGA7: molecular evolutionary genetics analysis version 7.0 for bigger datasets," Molecular Biology and Evolution, vol. 33, no. 7, pp. 18701874, 2016.

[54] F. Khan, N. K. Khattak, D. He, Y. L. C. Li, D. Ullah, and Y. Chen, "The complete mitochondrial genome organization of Schizothorax Plagiostomus (Teleostei: Cyprinidae) from Northern Pakistan," Mitochondrial DNA Part A, vol. 27, no. 5, pp. 3630-3632, 2016.

[55] S. Bibi and M. F. Khan, "Phylogenetic association of Schizothorax esocinus with other Schizothoracinae fishes based on protein coding genes," Mitochondrial DNA Part B, vol. 4, no. 1, pp. 352-354, 2019.

[56] T. K. Barik, S. N. Swain, B. Sahu, B. Tripathy, and U. R. Acharya, "Morphological and genetic analyses of the first record of longrakered trevally,Ulua mentalis(Perciformes: Carangidae) and of the pinjalo snapper,Pinjalo pinjalo(Perciformes: Lutjanidae) in the Odisha coast, Bay of Bengal," Mitochondrial DNA Part A, vol. 29, no. 4, pp. 552-560, 2018.

[57] X. Li, X. Shen, X. Chen, D. Xiang, R. W. Murphy, and Y. Shen, "Detection of potential problematic Cytb gene sequences of fishes in GenBank," Frontiers in Genetics, vol. 9, p. 30, 2018.

[58] Q. T. Bian, J. Q. Liu, X. Q. Luo, and J. L. Xiao, "Geotectonic setting, formation, and evolution of the Qinghai Lake," Seismology and Geology, vol. 22, pp. 20-26, 2000. 